\title{
FENOMENA PERILAKU POSITIF KASUS GIZI BAIK BALITA PADA KELUARGA MISKIN DI KELURAHAN TAMBELAN SAMPIT PONTIANAK TIMUR
}

\author{
Jahri $^{1}$ \\ ${ }^{1}$ Kementrian Kesehatan RI Poltekkes Kemenkes Pontianak \\ Korespondensi Penulis : j_jahri@yahoo.id
}

\begin{abstract}
Toodler is an age group with rapid body growth. However, toddler is also nutritionally vulnerable group and easily suffer from nutritional disorders. Various studies related to nutrition state that, nutritional status can be caused by medical conditions, socioeconomic status of the family which includes mother's education, mother's work status, family income, household food outcome, and socio-cultural environment. Nevertheless, secondary data in working area of Tambelan Sampit's Public Health Center, toddlers aged 0-59 months were $85 \%$ in good nutrition. This research aimed to explore, analyse, and describe the positive behaviour of housewives in form of parenting' feeding habits, parenting's cleaning habits and parenting's health service with toddler's good nutrition event from poor family in Tambelan Sampit Urban Village of Pontianak Timur District of Pontianak City. The type of this research was qualitative and the samples were 5 toddlers with good nutrition status from poor family. The samples were taken using purposive sampling, which the housewives were chosen selectively, and they must be the best housewives, would be selected as the research samples. The result showed that positive behaviour of parenting's feeding habits for toddlers was less eating but it was done regularly, giving additional foods, and giving suplementary vitamines. Parenting's cleaning habits involved washing hands before feeding the toddler, showering before the feeding, and taking care of the cleanliness of house and environment. While the positive behaviour of parenting's health service was such as coming to the Integrated Healthcare Center regularly to weigh and to observe the toddler's health every month, and if the toddler gets sick he or she must be brought to Public Health Center in order to get treatment. This research suggests to improve socialization about nutrition awareness family to increase mother's knowledge in feeding especially for toddler. It also involves the importance sanitation and hygene, joins the Integrated Healthcare Center regularly, socializes positive behaviours of toddler's mother from poor family which has been successfully maintained and stayed out of lack nutrition issue on toddlers by health staffs through various activities in Integrated Healthcare Center.
\end{abstract}

Keywords: Nutrition Status, Positive Behaviour, Poor Family

\begin{abstract}
ABSTRAK
Anak balita merupakan kelompok usia dengan pertumbuhan yang pesat dan rentan gizi. Beberapa penyebabnya adalahkondisimedis,statussosial ekonomi keluarga yang meliputi pendidikan ibu, status pekerjaan ibu, pendapatan keluarga, pengeluaran pangan rumah tangga, dan lingkungansosialbudaya.Data Puskesmas Tambelan Sampit menunjukkan anak usia $0-59$ bulan mencapai $85 \%$ balita gizi baik. Penelitian ini bertujuan untuk mengamati, menganalisis dan mendiskripsikan perilaku positif ibu balita berupa pola asuh kebiasaan pemberian makan, pola asuh kebiasaan kebersihan dan pola asuh kebiasaan mendapatkan pelayanan kesehatan dari keluarga miskin di Kelurahan Tambelan Sampit Pontianak Timur
\end{abstract}




\section{JPASDEV \\ Journal of Public Administration and Sociology of Development}

Kota Pontianak.Jenis penelitian kualitatif dansampel dalam penelitian ini adalah 5 balita dengan status gizi baik dari keluarga miskin. Pengambilan sampel dalam penelitian ini yaitu dengan caraPurposif sampling, yaitu ibu rumah tangga yang dipilih secara cermat, dan ibu rumah tangga yang terbaik, akan dipilih menjadi sampel penelitian. Hasil penelitian menunjukkan bahwa perilaku positif pola asuh pemberian makan keluarga pada balita adalah seperti makan sedikit tapi sering, selalu memberikan makanan tambahan, pemberian suplemen vitamin.Perilaku positif pola asuh kebiasaan kebersihan seperti selalu mencuci tangan sebelum menyuapi balita, selalu dimandikan sebelum diberi makan, kebersihan rumah dan lingkungan.Sedangkan perilaku positif pola asuh kebiasaan mendapatkan pelayanan kesehatan seperti selalu datang ke posyandu untuk menimbang dan memantau kesehatan balita setiap bulan, bila sakit anak selalu dibawa ke Puskesmas untuk mendapatkan perawatan. Penelitian ini menyimpulkan bahwa dari aspek perilaku positif pola asuh pemberian makan ibu balita memberikan makan porsi sedikit tapi sering, memberikan suplemen dan makanan tambahan, dari aspek pola asuh kebiasaan kebersihan ibu balita selalu menjaga kebersihan diri, balita dan lingkungan dan dari aspek pola asuh kebiasaan mendapatkan pelayanan kesehatan ibu balita selalu membawa balita ke posyandu dan puskesmas untuk memantau pertumbuhan balita dan perawatan kesehatan balita.

\section{Kata Kunci :Status Gizi, Perilaku Positif, Keluarga Miskin}

\section{PENDAHULUAN}

Anak balita merupakan kelompok usia dengan pertumbuhan badan yang pesat. Namun, balita juga dimana merupakan kelompok yang rentan gizi dan mudah menderita kelainan gizi.Hasil beberapa penelitian menyatakan bahwa penyebab status gizi buruk sering kali merupakan masalah yang kompleks dan sangat lokal spesifik, yang menyebabkan usaha-usaha perbaikan status gizi belum berhasil maksimal.Penyebab masalahnya tersebut dapat berbeda-beda pada daerah, lokasi, kelompok populasi walaupun pada wilayah yang sama. Penyebab masalah gizi tersebut sering berkaitan dengan perilaku dalam hal ini pola asuh gizi, dan dipengaruhi oleh lingkungannya (Oninla et al.,
2006;EviL,2010;Pryeretal.,2003).

Lingkungan dapat menyangkut aspek alam, sosial maupun budaya, dan merupakan faktor tidak langsung yang mempengaruhi status gizi. Berbagai penelitian yang berkaitan dengan gizi menyatakan bahwa, status gizi dapatdisebabkanolehkondisimedis,status sosial ekonomi keluarga yang meliputi pendidikan ibu, status pekerjaan ibu, pendapatan keluarga, pengeluaran pangan rumah tangga, dan lingkungansosialbudayaatausosiokultural(Sethi, 2007;Kanjilaletal.,2010;Beydoun,2011). Berdasarkan berbagai faktor yang diuraikan diatas, selain ditemukan balita 


\section{JPASDEV}

Journal of Public Administration and Sociology of Development

dengan kondisi status gizi yang bermasalah (malnutrition) pada lingkungan dan kondisi sosio-kultural yang sama terdapat sebagian balita dengan kondisi status gizi baik, yang di kenal dengan istilah penyimpangan positif (positive deviance), menurut penelitian Woro (2008) di daerah dengan positive deviance antara status gizi balita dan lingkungannya mendapatkan suatu model kemampuan untuk bertahan atau adanya potensi didalam masyarakat yang dapat mendukungterciptanya status gizi yang baik. Daerah dengan positive deviance adalah daerah yang mempunyai lingkungan rentan gizi atau daerah dengan lingkungan yang dapat mengakibatkan terjadinya gizi buruk dalam keluarga maupun masyarakat atau merupakan lingkungan yang tidak mendukung terciptanya gizi baik.Tetapi pada kenyataannya mempunyai gambaran status gizi

yangrelatifbaik(Lorongwaetal.,2009;Levinson, 2007; Piroska,2010).

Menurut data Riskesdas 2018 dari 34 provinsi di Indonesia, 17 provinsi memiliki prevalensi gizi kurang di atas angka prevalensi nasional yaitu berkisar antara $17,7 \%$ sampai dengan 29,5\%. Kalimantan Barat merupakan urutan ke 11 diantara 17 provinsi tersebut. Proporsi gizi kurang bila dibandingkan dengan tahun 2013 yaitu sebesar 13,9\%, tahun 2018 cenderung menurun yaitu sebesar $13,8 \%$ dan tahun sebelumnya tahun 2007 sebesar 13\%. Sedangkan proporsi gizi buruk mengalami fluktuatif yaitu pada tahun 2013 sebesar 5,7\%, tahun 2010 sebesar 4,0\% dan pada tahun 2007 sebesar 5,4\% dan terakhir tahun 2018 sebesar 3,9\%. Status gizi balita kota Pontianak pada tahun 2018 dengan status gizi buruk sebesar 9,02\%, status gizi kurang 18,01\% dan status gizi baik $86,74 \%$ serta status gizzi lebih sebesar $6,81 \%$. Selanjutnya gambaran status gizi balita di kelurahan Tambelan Sampit dengan status gizi baik sekitar $85 \%$ dan gizi kurang mencapai 15 $\%$.Secara keseluruhan balita dengan status gizi normal masih cukup tinggi di bandingkan dengan balita dengan status gizi kurang (Malnutrition) (Riskesdas 2018). Secara sosio geografi kelurahan tambelan sampit adalah pemukiman kumuh yang sulit untuk di tata, karena hampir sebagian besar rumah penduduk tidak memiliki lahan pekarangan disebabkan posisinya terletak di sepanjang bantaran sungai Kapuas, dengan kondisi akses jalan yang sempit dan rawan jatuh karena tinggi dan jalan masih ada yang terbuat dari papan. Secara ekonomi banyak yang masuk 


\section{JPASDEV}

Journal of Public Administration and Sociology of Development

pada kategori keluarga miskin, indikasinya adalah rumah kecil tidak layak huni, dengan penghasilan keluarga rata-rata dibawah 1 juta perbulan.Namun berdasarkan obsevasi awal peneliti tidak semua keluarga miskin yang ada di lokasi penelitian mengalami kekurangan gizi pada balita.

Sejak tahun 1998 pemerintah Kota Pontianak melakukan perbaikan gizi melalui langkah pengamanan yang disebut Social Safety Mate atau yang dikenal dengan jaring pengaman social. Dalam bidang kesehatan dikenal dengan Pemberian Makanan Tambahan (PMT) sebagai bagian dari Jaring Pengaman Sosial Bidang Kesehatan (JPSBK). PMT dilakukan dengan memberian makanan tambahan berupa telur, susu, biskuit pada anak-anak gizi buruk dan gizi kurang selama 90 hari. PMT JPS-BK kemudian menjadi idola tetapi masih menyisakan masalah besar akibat mewariskan karakter ketergantungan yang hebat, bukan saja pada level petugas kesehatan tetapi juga pada level masyarakat penerima bantuan. Seringkali bantuan yang diberikan berupa susu, telur dan biscuit bukan dikonsumsi oleh anak yang kurang gizi, tetapi malah dikonsumsi oleh orang tua atau anggota keluarga lainnya. Sehingga program ini bukannya menyelesaikan masalah, malah menimbulkan masalah baru yaitu
Vol. 2, N0.2, Desember 2021 ketergantungan.(Sirajuddin, 2014).

Pendekatan lain yang tak kalah penting yang pernah digalakkan oleh pemerintah Kota Pontianak adalah konsep pemberdayaan keluarga. Hingga saat ini konsep pemberdayaan keluarga dalam mengatasi gizi buruk masih jarang dilakukan, karena sulitnya untuk merumuskan bentuk intervensi yang melibatkan aspek income generating keluarga.Terlebih jika kemudian disimpulkan bahwa penyebab gizi buruk adalah sindroma kemiskinan.

Fenomena di atas menunjukkan bahwa dibutuhkan sebuah pendekatan yang lebih mengakar dan memberi hasil yang maksimal dalam menanggulangi masalah gizi buruk di Indonesia.Pendekatatan positive deviance sebagai salah satu pendekatan yang pernah sukses di Vietnam dalam menanggulangi masalah kekurangan gizi merupakan salah satu pilihan (alternative) yang dapat dijadikan pilihan.

Walaupun kekurangan gizi berhubungan erat dengan kemiskinan, akan tetapi sebagian anak dalam keluarga tertentu dengan sosial ekonomi yang rendah (miskin) mempunyai daya adaptasi yang tinggi sehingga mampu 


\section{JPASDEV}

Journal of Public Administration and Sociology of Development

tumbuh dan berkembang dengan baik (tidak kurang gizi). Mereka dapat keluar dari permasalahan yang sama (kekurangan gizi) ketika keluarga-keluarga miskin lainnya terbelenggu dalam masalah kekurangan gizi.

Padahal secara sosial ekonomi mereka sama dan hidup dalam lingkungan yang sama serta memiliki akses yang sama pula terhadap fasilitas kesehatan. Keluarga miskin yang memiliki anak yang sehat inilah yang disebut sebagai penyimpangan positif (positive deviance).

Oleh karena itu penelitian ini perlu dilakukan dengan judul "Fenomena Perilaku Positif Kasus Gizi Baik Balita Pada Keluarga Miskin Di Kelurahan Tambelan Sampit Pontianak Timur" untuk melakukan pengamatan, analisis dan diskripsi fenomena perilaku positif yang ada di masyarakat khususnya ibu rumah tangga pada keluarga miskindi Kelurahan Tambelan Sampit Kecamatan Pontianak Timur Kota Pontianak. Sehingga dapat dijadikan contoh penerapan perbaikan gizi pada keluarga lainnya yang memiliki balita gizi kurang dan dapat dijadikan sebagai bahan pertimbangan kebijakan dalam upaya perbaikan gizi di Kota Pontianak khususnya Kecamatan Pontianak Timur.

\section{METODE PENELITIAN}

1. Jenis Penelitian
Vol. 2, N0.2, Desember 2021 Penelitian ini menggunakan pendekatan penelitian kualitatif, karena dianggap lebih dapat untuk menjelaskan kondisi yang diteliti.Ada beberapa pertimbangan, kenapa metode kualitatif digunakan dalam penelitai ini. Pertama, sesuai dengan permasalahan, penelitian ini ingin menjelaskan mengapa beberapa keluarga tertentu dalam suatu komunitas yang memiliki sumberdaya yang sama lebih mampu dan berhasil dalam mengatasi masalah gizi buruk dibandingkan dengan keluarga lain dalam komunitas yang sama.

Disamping pertimbangan di atas, peneliti memilih menggunakan metode peneltian kualitatif karena informasi yang hendak dikumpulkan berupa pengetahuan, budaya, sikap dan perilaku ibu rumah tangga dalam mengasuh balita.Tahap awal yang harus dilakukan dalam rangka menyusunpetadaerahyang sesuai antara status gizi dan lingkungannya. Subyek berupa Institusi terkait dengan data sekunder yang akan diambil dari BPS Kota Pontianak,Dinas SosialKota Pontianak,DKKKota Pontianak dan Puskesmas Tambelan Sampit.

Daerah yang ditentukan sebagai unit analisis dalam penelitian ini 


\section{JPASDEV}

Journal of Public Administration and Sociology of Development

berdasarkan pemetaan daerah, verifikasi data dan diskusi dengan DKK Kota Pontianak, Puskesmas Tambelan Sampit, yang berkaitan dengan keterjangkauan transportasi, kemudahan komunikasi dan ketersediaan data pendukung demi kelancaran penelitian. Sehingga unit analisis kemudian ditentukan yaitu Kelurahan Tambelan SampitdiwilayahkerjaPuskesmas Tambelan Sampit, yang merupakan daerah pemetaan masalah dengan kategori sama yaitu rentan pendapatan dan ketersediaan pangan.

Sebagai subyek penelitian adalah keluarga miskin yang mempunyai balita diKelurahan Tambelan Sampit Kelurahan Kecamatan Pontianak Timur. Untuk memilih subyek dalam penelitian kualitatif tersebut terdapat kriteria yang harus dipenuhi, yaitu subyek menyatu dengan medan aktivitassasaranpenelitian, subyek memiliki waktu untuk dimintai informasi, subyek tidak memiliki hubungan spesial denganpeneliti.

Sumber data dalam penelitian ini dibedakan menjadi dua, yaitu data primer dan data sekunder.Data primer diperoleh melalui observasi dan wawancara.Adapun data sekunder diperoleh melalui review dokumen yang terkait dengan fokus penelitian.

\section{Lokasi Penelitian}

Lokasi penelitian berada di Kelurahan Tambelan Sampit Kecamatan Pontianak

Vol. 2, N0.2, Desember 2021 Timur Kota Pontianak, Provinsi Kalimantan Barat. Adapun alasan kenapa peneliti memilih tempat tersebut karena termasuk lingkungan padat penduduk, memiliki kesamaan pekerjaan, rata-rata penghasilan rendah yaitu dibawah 1 juta perbulan, berada sepanjang bantaran sungai Kapuas dan tidak memiliki lahan pekarangan untuk menanam.

\section{Subjek}

Subjek penelitian merupakan sumber data yang dapat memberikan informasi terkait dengan permasalahan penelitian yang diteliti seperti keluarga (ibu balita, suami, nenek, paman), tetangga sekitarnya.

Penelitian ini dilakukan dengan memprioritaskan klien/subjek ibu rumah tangga memiliki balita keluarga miskin di Kelurahan Tambelan Sampit Pontianak timur Kota Pontianak. Pengambilan sampel dilakukan dengan cara Purposif sampling, yaitu ibu rumah tangga yang dipilih secara cermat, dan ibu rumah tangga yang terbaik, akan dipilih menjadi sampel penelitian. Jumlah diambil secara sengaja, maksudnya peneliti menentukan sendiri sampel yang akan diambil tidak dilakukan secara acak karena ada pertimbangan tertentu. Adapun kriteria 


\section{JPASDEV}

Journal of Public Administration and Sociology of Development

sampel adalah ;

3.3.1.1. Subjek ibu rumah tangga memiliki balita gizi baik pada keluarga

miskin di Kota Pontianak.

\subsubsection{Keluarga Inti (ayah, ibu dan anak)}

3.3.1.3. Masyarakat terdekat dilingkungan subjek

4. Objek

Dalam penyusunan tesis ini, objek penelitiannya yaitu tentang Fenomena Perilaku Positif Kasus Gizi Buruk Balita Pada Keluarga Miskin di Kelurahan Tambelan Sampit Kecamatan Pontianak Timur Kota Pontianak.

\section{Teknik Pengumpulan Data}

Teknik pengumpulan data yang digunakan penulis dalam penelitian ini adalah sebagai berikut:

3.4.1.1. Observasi : Ingin mengetahui apa yang terjadi di lapangan dengan pengamatan secara langsung terhadap fenomenafenomena dari objek yang diamati dengan maksud memperoleh informasi yang sebenarnya cara ibu rumah tangga berperilaku positif terhadap pengasuhan balita.

3.4.1.2. Wawancara/Interview : Melakukan tanya jawab secara langsung kepada informan yang dianggap mengetahui permasalahan yang sesuai dengan objek penelitian. Dalam hal ini penulis meggunakan wawancara terbuka, artinya informan yang akan di
Vol. 2, N0.2, Desember 2021 wawancarai mereka yang mampu memberikan informasi-informasi sesuai dengan permasalahan yang di teliti sehingga peneliti mendapatkan data sesuai yang diinginkan.

\subsubsection{Dokumentasi :}

Dokumen berupa catatan, photo, atau data yang diperoleh dari Dinas Kesehatan Kota Pontianak dan Puskesmas Tambelan Sampit yang berkaitan dengan penelitian dari internet dan perpustakaan.Dokumen ini digunakan sebagai catatan tambahan dan penunjang dalam memberikan latar belakang yang lebih luas mengenai pokok penelitian.

6. Alat Pengumpulan Data

Mengingat pentingnya kelengkapan data dalam penyusunan penelitian maka untuk melakukan pengumpulan data terlebih dahulu dipersiapkan beberapa hal dibawah :

\subsubsection{Pedoman Observasi}

Alat bantu yang dipergunakan di dalam observasi yaitu daftar catatan, dimana peneliti mengobservosi aktivitas ibu rumah tangga, keluarga dekat (inti) dan tetangga sekitar rumahnya.

\subsubsection{Pedoman Wawancara}

Alat bantu yang dipergunakan dalam wawancara yaitu buku catatan dan handphone, dengan mencatat atau 


\section{JPASDEV}

Journal of Public Administration and Sociology of Development

merekam setiap jawaban yang diberikan oleh informan.

\subsubsection{Alat Dokumentasi}

Alat bantu yang dipergunakan dalam dokumentasi yaitu kamera dari handphone dan buku catatan.

\section{Teknis Analisis Data}

Analisis data kualitatif dilakukan dengan pemetaan data, mengorganisasikan data, memilah-milahnya menjadi satuan yang dapat dikelola, mensistensikannya, mencari dan menemukan pola, kemuadian menemukan apa yang penting dan apa yang dipelajari dan memutuskan apa yang dapat diceritakan kepada orang lain, yaitu melalui tiga komponen diantaranya:

3.4.2. Reduksi data, reduksi berarti merangkum dan memilih hal-hal yang pokok dengan demikian data yang telah direduksi akan memberikan gambaran yang lebih jelas dan memepermudah peneliti mengumpulkan data selanjutnya.

3.4.3. Display data (penyajian data) setelah dereduksi maka data di display. Penyajian data dilakukan dalam bentuk singkat. Hubungan kategori yang paling sering dilakukan adalah penyajian data dengan teks yang bersifat naratif.

Conlucion drawing verification, langkah selanjutnya adalah penarikan kesimpulan , dalam penarikan kesimpulan ini kesimpulan

Vol. 2, N0.2, Desember 2021 awal bersifat sementara dan masih bisa berubah saat ditemukannya bukti-bukti kuat yang mendukung pada tahap pengumpulan data berikutnya. Tapi apabila kesimpulan yang ditemukan pada tahap awal didukung bukti-bukti yang valid dan konsisten saat kembali melakukan pengambilan data di lapangan, maka kesimpulan yang ditemukan merupakan yang kredibel.

8. Teknis Keabsahan Data

Dalam penelitian kualitatif untuk mendapatkan data yang valid, kredibel dan obyektif, maka penelitian dilakukan pada sampel yang mendekati jumlah populasi dan pengumpulan serta analisis data yang benar. Temuan atau data dapat dikatakan valid dalam penelitian kualitatif apabila tidak ada perbedaan antara yang dilaporkan peneliti dengan apa yang sesungguhnya terjadi pada obyek penelitian (jenuh). Untuk memperoleh keabsahan data, maka peneliti yang dilakukan menggunakan metode triangulasi data. Sebagai berikut: 1.3.1. Verifikasi dengan Narasumber atau Informan

Triangulasi Sumber : untuk mengkaji kredibilitas dan keabsahan data dilakukan dengan cara mengecek data yang telah diperoleh melalui beberapa 


\section{JPASDEV}

Journal of Public Administration and Sociology of Development

narasumber atau informan

\subsubsection{Verifikasi Dengan Seorang Ahli}

Triangulasi ahli atau pakar : untuk mengkaji kredibilitas dan keabsahan data dapat pula dilakukan dengan cara mengcrosscheck data yang telah diperoleh melalui beberapa ahli atau pakar dibidangnya.

\subsubsection{Verifikasi Dengan Literatur}

Selain menggunakan metode triangulasi seperti diatas, peneliti juga dapat melakukan pengecekan data menggunakan literature atau referensi buku-buku, penelitian terdahulu seperti jurnal, skripsi dan akses internet.Referensi ini digunakan sebagai teori atau pedoman dalam penelitian. Pengujian keabsahan data dapat dilakukan dengan cara melakukan pengecekan dengan wawancara, observasi atau teknik lain dalam waktu/ situasi yang berbeda.

\section{HASIL DAN PEMBAHASAN}

\subsection{Hasil}

Dalam Bab ini menggambarkan hasil penelitian yang telah dilakukan, sesuai dengan tujuan yang digariskan dalam penelitian ini, yaitu mendiskripsikan perilaku positif pola asuh kebiasaan pemberian makan ibu balita gizi baik dari keluarga miskin, mendiskripsikan perilaku positif pola asuh kebiasaan kebersihan ibu balita gizi baik dari keluarga miskin dan mendiskripsikan

Vol. 2, N0.2, Desember 2021 perilaku positif pola asuh kebiasaan mendapatkan pelayanan kesehatan ibu balita gizi baik dari keluarga miskin di Kelurahan Tambelan Sampit Kecamatan Pontianak Timur.

5.1.1. Pola Asuh Kebiasaan Pemberian Makan

Wawancara ini sebagai ungkapan yang dijelaskan oleh informan (ibu balita) dalam melakukan upaya keluarga memenuhi kebutuhan nutrisi balita. Dari beberapa yang sudah diungkapkan oleh informan didapatkan prinsip pemberian makanan. Informan mengatakan bahwa jika anak balita tidak mau makan, maka upaya yang dilakukan untuk memenuhi kebutuhan nutrisi adalah dengan cara memberikan makan dengan porsi sedikit tapi sering, memberikan susu formula, dan memberikan cemilan. Kategori sedikit tapi seringtergambar dari ungkapan informan tiga berikut ini :

“...ini kalau makannya sedikit-sedikit begini lebih sering sih saya kasihkan...."(I3).

Ungkapan Informan dua menjelaskan bahwa pemberian susu formula dilakukan sebagai alternatif makanan untuk pengganti asupan agar balita masih tetap dapat asupan makanan 


\section{JPASDEV}

Journal of Public Administration and Sociology of Development

meskipun tidak makan nasi. Hal ini ungkapkan oleh informan sebagai berikut :

“...kalau malam nih makannya gak mau ...udah dikasih susu aja...siang juga sih kalau dia gak mau makan saya kasih susu.”(I2).

Sedangkan informan lima menjelaskan bahwa ia memberikan cemilan jika anaknya tidak mau makan, seperti ungkapan berikut ini:

“...yah di kasih cemilan aja roti....terus sosis yang itu tuh...so nice..."(I3)

Keluarga sudah melakukan berbagai upaya yang dilakukan yaitu dengan menerapkan prinsip pemberian makan. Lebih lanjut keluarga juga menggambarkan strategi yang sudah dilakukan keluarga dalam memenuhi kebutuhan nutrisi balita.

Strategi yang digunakan keluarga dalam memenuhi kebutuhan nutrisi balita; Informan satu menyatakan strategi yang digunakan keluargadalam memenuhi kebutuhan nutrisi balita adalah dengan cara memberikan vitamin, mengajak anak untuk bermain, menyiapkan makanan sesuai dengan selera anak, dan dengan cara memberikan reward/punishment. Umumnya informan memberikan vitaminpenambah nafsu makan yang berbahan dasar curcuma seperti yang diungkapkan oleh informan berikut ini:

“...dikasih vitamin..pernah dikasih
curcuma..'(I1)

Selain itu, ada dua Informan yang memberikan obat penambah nafsu makan dalam bentuk ramuan tradisionalyaitu jamu seduh yang terbuat dari temu lawak atau biang kunyit, seperti yang diungkapkan oleh informan di bawah ini:

“...kalau dia tidak mau...sampai saya tegukkan....."(I5).

Strategi lain yang pernah dilakukan oleh keluarga dalam mengatasi anak yang susah makan adalah dengan cara mengajak anak untuk bermaindi luar rumah atau di dalam rumah, yang diungkapkan oleh informan empat berikut ini :

“...dia mau makan kadang-kadang harus main, kadang-kadang di rumah aja. "(I4).

Sementara informan lain menyatakan bahwa kadang -kadang jika anaknya tidak mau makan maka yang dilakukan oleh informan adalah dengan cara membohongi anak balita yang bersifat reward dan punishment, seperti yang dilakukan oleh informan lima di bawah ini :

“...sama dibohongin kalau pergi gitu..tapi pergi gak diajak gitu..”(I5)

Cara lain yang dilakukan oleh informan 


\section{JPASDEV}

Journal of Public Administration and Sociology of Development

dalam penelitian ini adalah dengan cara memberikan stimulasi atau pemijatan pada anak balita jika anak balita sudah tampak rewel dan tidak mau makan. Hal ini diungkapkan oleh informan satu seperti di bawah ini:

“...dari bayi juga suka di urut..pokoknya kalau udah rewel-rewel saya urut..."(I1)

Hal lain yang dilakukan adalah kategori mengikuti kesukaan anak seperti yang diungkapkan oleh informan di bawah ini :

“...dia sukanya pakai kecap...apa telornya dikecapin...ayam pakai kecap gitu aja..”(I5).

\subsubsection{Pola Asuh Kebiasaan Kebersihan}

Wawancara ini ungkapan yang dijelaskan oleh keluarga (ibu balita) dalam melakukan upaya keluarga dalam menjaga kebersihan. Dari beberapa yang sudah diungkapkan oleh informan didapatkan beberapa hal tentang kebersihan. Hampir semua informan mengatakan bahwa sebelum memberikan makan anak dalam keadaan bersih, sudah rapi atau sudah mandi, demikian juga ibu balita selalu mencuci tangan sebelum menyuapi anak makan. Berdasarkan pengamatan, dari ke lima tempat tinggal informan cukup bersih dan nyaman, walaupun tempat dengan ukuran yang kecil dan sangat tidak layak untuk perkembangan anak, namun mereka mampu menjaga
Vol. 2, N0.2, Desember 2021 kebersihan tempat tinggal.

Kategori lingkungan dan diri bersihtergambar dari ungkapan informan satu, dua, tiga dan empat berikut ini :

“...ini kalau mau ngasih makan harus bersih dulu...mandi..wangi-wangi....”. “...sebelum berangkat kerja saya yang nyiapin makanannya, biar yakin udah bersih, baru itu minta bantu neneknya yang nyuapin...".

Ungkapan informan menjelaskan bahwa menjaga kebersihan dilakukan sebagai upaya untuk menjaga kesehatan balita mereka, karena atas dasar kesadaran salah satu informan yang pernah balitanya terkena diare.

5.1.3. Pola Asuh Kebiasaan Mendapatkan Pelayanan Kesehatan

Pada tahap ini wawancara yang dihasilkan adalah mengungkap kesadaran keluarga selalu membawa balita ke fasilitas pelayanan kesehatan seperti Posyandu atau Puskesmas. Perasaan Informan terhadap kondisi balita dirasakan oleh keluarga sebagai respon secara psikologis dan respon sikap. Respon secara psikologistergambar dari adanya perasaan cemas. Perasaan cemas tergambar dari pernyataan tiga orang 


\section{JPASDEV}

Journal of Public Administration and Sociology of Development

informan yang menjelaskan bahwa

Vol. 2, N0.2, Desember 2021

informanmerasakanresah,khawatir,takut,dan bingungjikaberatbadan anaknya tidak naik setiap bulan. Kategori Perasaan resah dan khawatir dinyatakan oleh informan dua dan empat yang anaknya mengalami perubahan berat badan yang kadang naik dan kadang turun. Hal ini diungkapkan oleh informan berikut ini :

“...yah khawatir saja sih....kan kalau itu kan harusnya tiap bulan naik....biar berapa ons lah atau sekilo, harus naiklah dia ....”(I2). “...yah khawatir aja sih dibilang kurang gizi ....'(I4)

Sedangkan informan tiga menyatakan perasaan bahwa keluarga merasa takutjika berat badan anaknya tidak naik setiap bulannya dan juga mengalami penurunan drastis semenjak anaknya berumur setahun dua bulan, seperti diungkapkan berikut ini : “....takut juga kalau berat badannya gak naiknaik...."(I3).

Kategori lain adalah dinyatakan oleh informan satu dan lima yang merasakan penasaran dan bingung dengan berat badan anaknya yang tidak pernah naik, seperti yang diungkapkan oleh informan berikut ini :

“....saya penasaran nih anak makannya doyan, tapi segitu - segitu aja gak naik ...yah penasaran sih bingung gimana yah...”(I1) “...ya nih makanya bingung, badannya segitu-segitu aja..."(I5)

Sedangkan informan empat menyatakan bahwa informan menerimapertumbuhan balita yang mengalami gizi kurang dan dirasakan lebih baik bila dibandingkan dengan kondisi saudara/kakak kandungnya yang juga mengalami gizi kurang. Hal ini diungkapkan seperti di bawah ini:

“...mendingan lah dari pada kakaknya..."(I4)

Penyebab lain yang dijelaskan oleh informan adalah tema kesakitan dengan kategori sering sakit dan adanya gangguan kesehatan.Kategori sering sakit diungkapkan oleh empat informan yang menyatakan bahwa hampir setiap bulan anak balita mengalami sakit seperti demam, batuk pilek, dan radang tenggorokan, sehingga mempengaruhi status gizi anak balita. Berikut ini adalah ungkapan informan satu, empat dan lima: “...waktu bayi juga sering sakit panas, batuk, pilek, ..ya sebulan ada lah sekali...."(I1)

“...hampir tiap bulan panas, demam tinggi, batuk, pilek ....”(I4) “... seringnya sih itu ..penyakit radang gitu yah...'(I5). Kategori lain dari tema kesakitan dinyatakan oleh informan karena balita sering mengalami gangguan 


\section{JPASDEV}

Journal of Public Administration and Sociology of Development

kesehatanseperti yang diungkapkan oleh informan dua dan empat berikut ini:

“...iya pengaruh banget kalau lagi sakit makannya kurang....”(I2) “......Kalau batuk dia berasa banget cepet kurus dia itu...”(I4).

Dari hasil wawancara diatas terlihat bahwa keluarga sudah dapat menyatakan tentang faktor- faktor penyebab anak balita mengalami gizi kurang.Sehingga keluarga selalu memanfaatkan fasilitas kesehatan seperti Puskesmas dan Posyandu untuk memeriksakan dan konsultasi kesehatan anaknya.

\subsection{Pembahasan}

Berdasarkan hasil penelitian diatas, peneliti dapat mendiskripsikan sesuai dengan tujuan yang akan dicapai yaitu ; mendiskripsikan perilaku positif pola asuh kebiasaan pemberian makan ibu balita gizi baik dari keluarga miskin, mendiskripsikan perilaku positif pola asuh kebiasaan kebersihan ibu balita gizi baik dari keluarga miskin dan mendiskripsikan perilaku positif pola asuh kebiasaan mendapatkan pelayanan kesehatan ibu balita gizi baik dari keluarga miskin di Kelurahan Tambelan Sampit Kecamatan Pontianak Timur.

5.2.1. Perilaku positif pola asuh kebiasaan pemberian makan ibu balita gizi baik dari keluarga miskin

Berdasarkan hasil yang telah di uraikan diatas

Vol. 2, N0.2, Desember 2021 bahwa, fakta dilapangan menunjukkan upaya yang dilakukan keluarga terutama ibu balita di antaranya adalah selalu berusaha memperhatikan asupan balitanya. Walaupun secara umum dari ke lima balita tersebut susah diberi makan. Menurut prinsip pemberian makanan balita, strategi yang dilakukan sudah tepat, yaitu diberikan dengan porsi kecil tapi sering sehingga asupan tetap tercukupi. Kemudian balita juga diberikan suplemen seperti vitamin baik berupa syrup maupun dari buah-buahan segar sesuai kemampuan keluarga untuk membeli. Selain itu ibu balita sering memberikan selingan minum susu apabila balita minta ataupun tidak minta. Ini adalah sebuah sikap dan prilaku positif ibu balita tepat. Salah satu informan menyatakan bahwa pendapatan keluarga yang kurang sehingga menyebabkan pemenuhan kebutuhan makanan untuk balita tidak optimal. Hal ini didukung dengan data demografi informan didapatkan rata - rata penghasilan keluarga adalah dibawah satu juta.

Penelitian ini mendukung hasil penelitian yang telah dilakukan oleh Basuki (2003) tentang faktor-faktor yang berhubungan dengan status gizi bawah dua tahun 


\section{JPASDEV}

Journal of Public Administration and Sociology of Development

(baduta) didapatkan hasil bahwa faktor yang paling berpengaruh adalah tingkat ekonomikeluarga. Yang menarik adalah beberapa ibu balita sebagai single parent karena cerai dan beberapa suami pengangguran dan sisanya suami hanya buruh yang berpenghasilan tidak menentu. Namun keluarga ini memiliki balita dengan status gizi baik dan sehat. Hasil penelitian ini juga mendukung pendapat yang dikemukakan oleh Soekirman (2008) bahwa faktor-faktor yang dapat menyebabkan terjadinya gizi kurang pada balita dapat dikelompokan menjadi penyebab langsung dan tidak langsung. Penyebab langsung gizi kurang adalah makan tidak seimbang, baik jumlah dan mutu asupan gizinya, di samping itu asupan zat gizi tidak dapat dimanfaatkan oleh tubuh secara optimal karena adanya gangguan penyerapan akibat adanya penyakit infeksi. Anak balita tidak cukup mendapat makanan bergizi seimbang. Makanan alamiah terbaik bagi bayi yaitu Air Susu Ibu (ASI), dan sesudah usia 6 bulan anak tidak mendapat Makanan Pendamping ASI (MP-ASI) yang tepat, baik jumlah dan kualitasnya akan berkonsekuensi terhadap status gizi bayi. MP- ASI yang baik tidak hanya cukup mengandung energi dan protein, tetapi juga mengandung zat besi, vitamin A, asam folat, vitamin B serta vitamin dan mineral lainnya. MP-ASI yang tepat dan baik

dapat disiapkan sendiri di rumah.

Pada keluarga dengan tingkat pendidikan dan pengetahuan yang rendah seringkali anaknya harus puas dengan makanan seadanya yang tidak memenuhi kebutuhan gizi balita karena ketidaktahuan. Dari fakta ini keluarga dapat di jadikan sebagai satu rekomendasi bagi percontohan bagi keluarga lainnya yang balitanya mengalami gizi kurang dan bahkan gizi buruk.

5.2.2. Perilaku positif pola asuh kebiasaan kebersihan ibu balita gizi baik dari keluarga miskin

Terkait dengan pola asuh kebiasaan kebersihan, dari fakta yang didapatkan dilapangan bahwa ibu balita selalu memperhatikan kebersihan diri, balita dan lingkungan. Berdasarkan pengamatan dilapangan kondisi tempat tinggal dan lingkungan sangat tidak cocok untuk pertumbuhan dan perkembangan balita, karena tidak ada tempat bermain, kumuh, ruang kecil dan rawan jatuh karena kondisi rumah tinggi dan hanya dilalui jembatan kecil. Ketika peneliti datang ke rumah informan, kondisi rumah cukup bersih dan hampir tidak ada lalat dengan rata-rata ruang tamu berukuran $2 \times 2$ meter persegi 


\section{JPASDEV}

Journal of Public Administration and Sociology of Development

dengan perabot rumah tangga seadanya. Peneliti berpandangan keluarga mempunyai kesadaran bahwa kebersihan penting untuk di jaga, salah satu alasannya karena pengalaman balita pernah diare. Walaupun aspek kebersihan tidak berpengaruh secara langsung terhadap status gizi balita, dan kondisi rumah kecil dan bahkan tidak layak huni, aspek ini juga merupakan potensi di masyarakat berupa prilaku positif yang dapat menjadi salah satu rekomendasi bagi keluarga lainnya yang memiliki masalah gizi balita. Menurut Soekirman (2008) dijelaskan bahwa masih tingginya tingkat penyakit Infeksi yang terjadi di Indonesia disebabkan karena kondisi kesehatan dan kesadaran akan kebersihan / personal hygine yang masih kurang. Kebiasaan dan kesadaran masyarakat akan pentingnya kebersihan/personal hygiene masih kurang sehingga menyebab tingginya angka kejadian infeksi di Indonesia. Dalam penelitian ini belum tergali secara mendalam tentang kebiasaan masyarakat dalam hal kebersihan diri karena menurut peneliti hubungan antara kebersihan diri dengan kejadian gizi kurang tidak terlalu signifikan (penyebab tidak langsung).

5.2.3. Perilaku positif pola asuh kebiasaan mendapatkan pelayanan kesehatan ibu balita gizi baik dari keluarga miskin

Berdasarkan apa saja yang diungkapkan oleh
Vol. 2, N0.2, Desember 2021 ibu balita pada penelitian ini, bahwa hampir semua informan memiliki pemahaman baik terhadap pentingnya selalu membawa balita ke fasilitas pelayanan kesehatan apabila balita sakit atau tidak naik berat badannya untuk di konsultasikan baik penyakit maupun gizinya. Fakta dilapangan ibu balita selalu membawa anaknya setiap bulan ke Posyandu untuk di timbang dan konsultasi tentang pertumbuhan dan perkembangan balitanya.Bahkan di bawa ke Puskesmas apabila balita sakit untuk mendapatkan perawatan maupun pengobatannya. Alasan lain adalah karena keterbatasan keuangan mereka tidak mampu untuk membawa anaknya ke tempat yang lebih jauh lagi. Di Posyandu ibu balita sering mendapat pelatihan bagaimana mengolah makan untuk balita yang berbahan pangan lokal murah dan mudah di dapat.Selain itu ibu balita juga mendapatkan suplemen secara gratis, sejalan dengan pendapat upaya mengatasi masalah gizi kurang memerlukan peran perawat komunitas. Hitchock, Schubert, dan Thomas (1999) menjelaskan bahwa intervensi keperawatan yang dapat dilakukan untuk mengatasi masalah nutrisi adalah dengan melakukan pengkajian sumber ekonomi 


\section{JPASDEV}

Journal of Public Administration and Sociology of Development

dan kebiasaan makan keluarga, memberikan edukasi tentang nutrisi balita, memberikan suplemen vitamin, dan kunjungan rumah dalam rangka pengobatan dan perawatan.

\section{SIMPULAN DAN SARAN}

\subsection{Simpulan}

Berdasarkan hasil penelitian dan pembahasan sebagaimana dikemukakan sebelumnya, maka hasil penelitian ini dapat disimpulkan sebagai berikut :

4.1.1. Perilaku positif pola asuh pemberian makan dari ke lima informan secara fakta terbukti keluarga dapat mengatasi masalah anak balita gizi kurang seperti makan sedikit tapi sering, pemberian makan cemilan dan pemberian susu formula merupakan tindakan yang sesuai yang diharapkan dapat meningkatkan dan merubah status gizi balita. Pemijatan secara rutin, pemberian jamu temu lawak merupakan perawatan kesehatan yang dilakukan keluarga terkait pemenuhannutrisi, sehingga balita sehat dan status gizinya baik.

4.1.2. Perilaku positif pola asuh kebiasaan kebersihan dari ke lima informan terbukti mampu mengurangi kasus kesakitan pada balita dengan indikasi ibu balita selalu menjaga kebersihan diri, balita dan lingkungan dalam upaya mencegah sumber penyakit yang mudah menyerang balita dan keluarga lainnya, walaupun dengan kondisi

Vol. 2, N0.2, Desember 2021 yang serba terbatas.

4.1.3. Perilaku positif pola asuh pemanfaatan pelayanan kesehatan oleh ke lima informan sudah cukup baik, dengan selalu datang ke posyandu untuk menimbang balitanya dan memeriksakan kesehatan balitanya ke Puskesmas paling sedikit sebulan sekali, sehingga apabila balita sakit atau berat badannya tidak naik tidak terjadi menjadi lebih parah lagi dan segera dapat di atasi.

\subsection{Saran}

\subsubsection{Kepada Pemerintah}

Untuk mempertahankan fenomena perilaku positif dalam keluarga yaitu pola asuh kebiasaan pemberian makanan, pola asuh kebiasaan kebersihan dan pola asuh pemanfaatan pelayanan kesehatan padahal secara ekonomi adalah keluarga miskin dan tidak mampu, pemerintah perlu memberikan dukungan baik secara moril maupun materil. Secara moril diberikan reward agar keluarga tetap bersemangat, sedangkan secara materil keluarga perlu peningkatan ekonomi, sehingga dapat hidup lebih layak lagi.

4.2.2. Kepada Keluarga (Ibu Balita)

Untuk mempertahankan dan menjaga kondisi keluarga (balita) supaya tetap sehat dan gizi baik, perilaku positif yaitu 


\section{JPASDEV}

Journal of Public Administration and Sociology of Development

pola asuh kebiasaan pemberian makanan, pola asuh kebiasaan kebersihan dan pola asuh pemanfaatan pelayanan kesehatan yang sudah dilakukan oleh keluarga harus dipertahankan, karena hal akan berdampak kepada kondisi dan hidup balita sebgai generasi penerus keluarga, walau saat ini kondisi ekonomi keluarga sangat memprihatinkan dan hidup dalam keadaan pas-pasan. Selain itu perilaku positif ini dapat menjadi contoh bagi keluarga lainnya yang mengalami masalah gizi balita.

\section{Referensi}

Almatsier, S. (2017). Prinsip Dasar Ilmu Gizi. Jakarta: Gramedia Pustaka Utama.

Atmarita dkk, (2015)..Pendek (Stunting) di Indonesia Masalah dan Solusinya, Balitbangkes, Kemenkes.

Basuki, C. (2006). Pengantar Kesehatan Lingkungan,Bandung: Rosda Karya.

Badan Pusat Statistik. (2015). Penghitungan dan Analisis Kemiskinan Makro di IndonesiaTahun 2015. Jakarta.

CORE. (2003). Positive Deviance \& Health, Suatu Pendekatan Perubahan Perilaku \& Pos Gizi.Diterjemahkan Oleh PCI Indonesia. Jakarta.

Evi L. B. (2010). PrevalensiDan Determinan Kejadian Gizi Kurang Pada Balita (Studi Kasus Pada Keluarga Nelayan Di Desa Bajumulyo Kecamatan Juwana Kabupaten Pati). Jurnal Kesmas, 5 (2):165-172.

Jamaludin A. (2015). Sosiologi PedesaanPenerbit CV Pustaka Setia
Vol. 2, N0.2, Desember 2021

Bandung.

Kementerian Kesehatan RI. (2017). Profil Kesehatan Indonesia Tahun 2016. -- Jakarta.

Miles, M. B. \& Huberman, M. (2009). Analisis Data Kualitatif. Jakarta: Penerbit Universitas Indonesia.

Moleong, L J. (2013). Metode Penelitian Kualitatif. Edisi Revisi. Bandung : PT. Remaja Rosdakarya.

Notoatmodjo, S. (2010). Ilmu Perilaku Kesehatan. Jakarta: PT Rineka Cipta.

Riset Kesehatan Dasar (2018) Badan Penelitian dan Pengembangan Kesehatan Kementerian Kesehatan Republik Indonesia.

Sirajuddin, dkk. (2014). Survei Konsumsi Pangan. EGC: Jakarta.

Soekirman. (2011) Ilmu Gizi dan Aplikasinya untuk Keluarga dan Masyarakat. Jakarta: Direktorat Jenderal Pendidikan Tinggi Departemen Pendidikan Nasional.

Sugiyono. (2016). Metode Penelitian Kuantitatif Kualitatif, dan R \& D Bandung: Alfabeta.

Supariasa, I. D., Bakri, B., \& Fajar, I. (2016).Penilaian Status Gizi. Jakarta: Penerbit Buku Kedokteran EGC.

Suryawati, C. (2005). Memahami Kemiskinan Secara Multidimensional.JMPK Vol. 08/No.03/September/2005.Fakulta s Kesehatan Masyarakat dan Magister Ilmu Kesehatan Masyarakat Universitas Diponegoro, Semarang, Jawa 


\section{JPASDEV}

Journal of Public Administration and Sociology of Development

Tengah.

Zeitlin, M., H. M. (1990). Positive deviance in child nutritionwith emphasis on psychosocial and behavioural aspects and implications for development. Tokyo: The
Vol. 2, N0.2, Desember 2021

United Nations University. [online]. Tersedia: h t t p s : / / s 3 . a m a z on a w $\mathrm{s}$ $\mathrm{c} \quad \mathrm{O} \quad \mathrm{m}$ /academia.edu.documents/30201659/pos dev.pdf. [18 Mei 2018] 